\title{
Analisis Strategi UMKM Jiwaku Ricebowl dalam Menghadapi Pandemi Covid -19
}

\author{
Anindita Nurjihan Dwi T. ${ }^{1}$, Muhamad Rizal ${ }^{2}$ Ria Arifianti ${ }^{3}$ Asmaul Husna $^{4}$ \\ 1,2,3 Universitas Padjadjaran, Bandung, Jawa Barat, Indonesia \\ ${ }^{4}$ Universitas Maritim Raja Ali Haji, Tanjungpinang, Kepulauan Riau, Indonesia
}

\begin{abstract}
ABSTRAK : Pada 10 Maret 2020, awal mula dimulainya pandemic Covid-19 ini menyebabkan dampak yang dirasakan oleh beberapa negara, bahkan pemerintah dan masyarakat. Salah satu dampak yang dirasakan tidak hanya masalah kesehatan namun juga menyerang perekonomian di Negara contohnya UMKM sebagai sektor Usaha Mikro Kecil dan Menengah mengalami dampak yang parah disebabkan oleh pandemic Covid-19. Bersumber pada informasti yang diolah P2E LIPI, dampak penyusutan pariwisata terhadap UMKM yang bergerak dalam usaha makanan dan minuman mikro menggapai $27 \%$. Sedangkan dampak terhadap usaha kecil makanan dan minuman sebesar $1,77 \%$ serta usaha menengah di angka $0,07 \%$. Riset ini diperuntukan untuk memandang sepanjang mana pertumbuhan pandemi Covid-19 serta bagaimana dampak terhadap perekonomian di Negeri Indonesia terutama UMKM. Afifuddin Suhaeli Kalla mengatakan bahwa pemasukan dari UMKM mengalami penurunan hingga 70\% sejak pandemi Covid-19 dan omzet ini menurun dirasakan juga oleh usaha Jiwaku setelah di berlakukannya PSBB pendapatan dari Jiwaku ini menurun 70\% dari biasanya dan mengalami penutupan sementara selama 2 minggu dengan arahan dari pemerintah dikarenakan kota Bandung banyak yang terpapar virus. Riset ini dilakukan untuk mengenali apa yang dilakukan pelaku UMKM agar bisa mempertahankan bisnis mereka di masa Pandemi covid-19 ini. Riset ini bertujuan untuk mendeskripsikan serta menjabarkan strategi apa yang hendak dicoba oleh pelaku UMKM agar sanggup terus bertahan serta menjadi lebih responsive terhadap pergantian iklim bisnis melalui analisis SWOT. Riset ini memakai pendekatan riset kualitatif deskriptif serta Analisis SWOT guna mencerna serta menciptakan suatu rumusan strategi.
\end{abstract}

Kata kunci: Strategi UMKM, Pandemi, Covid-19, Strategi Pandemi, UMKM

\begin{abstract}
On March 10, 2020, the start of the Covid-19 pandemic caused an impact that was felt by several countries, even the government and society. One of the impacts that is felt is not only a health problem but also attacks the country's economy, for example MSMEs as the Micro, Small and Medium Enterprises sector are experiencing a severe impact due to the Covid-19 pandemic. Based on information processed by LIPI's P2E, the impact of tourism shrinkage on MSMEs engaged in the micro food and beverage business reached $27 \%$. Meanwhile, the impact on small food and beverage businesses was $1.77 \%$ and medium enterprises was $0.07 \%$.

This research is intended to see where the Covid-19 pandemic has grown and how it impacts the economy in Indonesia, especially MSMEs. Afifuddin Suhaeli Kalla said that income from MSMEs has decreased by $70 \%$ since the Covid-19 pandemic and this decreased turnover was also felt by Jiwaku's business after the PSBB was implemented. government because the city of Bandung has been exposed to the virus. This research was conducted to identify what MSME players were doing in order to maintain their business during the Covid-19 Pandemic. This research aims to describe and describe what strategies MSME actors want to try in order to be able to continue to survive and become more responsive to changes in the business climate through a SWOT analysis. This research uses a descriptive qualitative research approach and SWOT analysis to digest and create a strategy formulation.
\end{abstract}

Keywords: MSME Strategy, Pandemic, Covid-19, Pandemic Strategy, MSME

Email Address : anindita20001@ mail.unpad.ac.id ${ }^{1}$, muhamad.rizal@mail.unpad.ac.id r.arifianti@mail.unpad.ac.id ${ }^{3}$, asmaulhusna@umrah.ac.id ${ }^{4}$ 
FE Universitas Maritim Raja Ali Haji

\section{Pendahuluan}

Pada 10 Maret 2020 Indonesia mengalami dampak besar akibat virus corona, virus ini merupakan suatu wabah yang tidak bisa dianggap sepele bahkan menurut analisis medis virus ini lumayan beresiko serta mematikan. Di tahun 2020, pertumbuhan penularan virus covid-19 lumayan signifikan sebab penyebarannya telah mendunia serta seluruh Negara merasakan akibatnya terutama di Indonesia (Yunus, 2020).

Salah satu dampak dari pandemi Covid19 adalah UMKM di Indonesia, menurut data dari kementrian koperasi yang menggambarkan bahwa 1.785 koperasi serta 163.713 pelaku Usaha Mikro Kecil dan Menengah (UMKM) terdampak pandemic Covid-19. Cara untuk menanggulangi masalah yang dihadapi pelaku UMKM dan koperasi, pemerintah membuat beberapa upaya yaitu dengan memasukan pelaku UMKM dan koperasi sebagai penerima program bantuan pemerintah seperti Kartu Prakerja, subsidi tariff listrik, dan Keluarga Harapan.

Pemerintah pun memberikan keringanan pembayaran pajak dari bulan April 2020 hingga September 2020 berjalan 6 bulan, terjalin penyusutan penyerapan produk-produk UMKM berimbas kepada penyusutan omset di UMKM itu sendiri, Afifuddin Suhaeli Kalla mengatakan bahwa pemasukan UMKM menurun sampai $70 \%$ semenjak pandemi Covid-19. Maka dari itu pelaku UMKM harus menerapkan strategi terbaru yang lebih efektif contohnya seperti melakukan penjualanan secara online yang bisa juga di secbut $e$ commerce. E-commerce ialah sistem penjualan, pembelian serta memasarkan produk menggunakan elektronik (Kotler, Philip dan Amstrong, 2012).

Dalam riset (Hardilawati, 2019b) serta (Setyorini et al., 2019) merumuskan kalau ecommerce mempunyai pengaruh positif signifikan terhadap kenaikan kinerja pemasaran serta pemasukan UMKM.
Ecommerce merupakan kegiatan transaksi berupa jual beli produk yang medianya menggunakan elektronik antar individu atau kelompok (Achmad Alfin, 2021). Namun, apabila sudah melakukan penjualanan melalui e-commerce, pelaku UMKM juga perlu memakai digital marketing serta menggunakan digital marketing untuk bisa menjangkau konsumennya secara langsung serta bisa menekan biaya promosi. (Wan Laura 2020). Digital marketing membantu perusahaan atau pelaku usaha dalam mempromosikan dan memasarkan produk dan jasa mereka dan mampu memperluas pasar baru yang sebelumnya tertutup atau terbatas karena adanya keterbatasan waktu, jarak dan cara berkomunikasi (Prabowo, 2018).

Berdasarkan survey Bank DBS mengenai minat kosumen dalam menggunakan e-commerce terdapat peningkatan yang melonjak, seperti contohnya konsumen pengguna e-commerce sebelum pandemi tercatat sebesar $24 \%$ dan naik menjadi $66 \%$ saat pandemic covid-19. Menurut penjelasan diatas bahwa sudah seharusnya pelaku usaha mulai melakukannya melalui e-commerce ini dan meningkatkan kualitas produk dan pelayanan agar konsumen percaya dan mau membeli kepada mereka. Hal ini sesuai dengan penelitian (Tipyana \& pramono, 2020) dimana kualitas yang baik dapat meningkatkan kepuasan konsumen dapat menumbuhkan hubungan yang baik antar pelaku usaha dan konsumen.

Oleh kementerian Keuangan mengkaji bahwa pandemi Covid-19 memberiikan dampak negatif bagi perekonomian domestic seperti penurunan konsumsi dan daya beli masyarakat, eksistensi UMKM, ancaman pada sektor perbankan dan keuangan, penurunan kinerja perusahaan (Santoso, 2020). Salah satu umkm dari Jiwaku Ricebowl yang juga merasakan dampak dari 
adanya virus Covid-19. Usaha Jiwaku Ricebowl berdiri sejak tahun 2019 dengan modal awal Rp.7.000.000 sudah cukup untuk 6 pilihan menu makanan seperti daging ayam crispy dengan resep rahasia. Pada tanggal 10 Maret 2020 virus corona mulai memasuki negara Indonesia dan diberlakukan Pembatasan Sosial Berskala Besar (PSBB). Namun dikarenakan lokasi di Taman Cibeunying kurang kondusif sehingga owner dari jiwaku ini akan menfokuskan kepada cabang yang ada di Contou.

Jika dilihat dari klasifikasi UMKM usaha Jiwaku ricebowl sudah termasuk Fast Moving Enterprise karena jiwaku ricebowl ini sudah

bergabung dengan Contou coffee sehingga merupakan Usaha Mikro Kecil dan Menengah (UMKM) yang akan melakukan transformasi menjadi usaha besar (UB) dan memiliki jiwa usaha yang baik. Data Kementrian Koperasi dan Usaha Kecil dan Menengah Indonesia tahun 2018 membuktikan jumlah unit usaha ataupun 62,9 juta unit. UMKM meresap $97 \%$ dari total penyerapan tenaga kerja, $89 \%$ di antara lain terdapat di zona mikrom serta menyumbang $60 \%$ terhadap produk domestic bruto (Kemenkop dan UMKM, 2018).

Riset ini dicoba buat mengenali apa yang dilakukan pelakon UMKM buat bisa mempertahankan bisnis mereka di masa pandemic covid-19 ini. Riset ini bertujuan buat mendeskripsikan serta menjabarkan strategi apa yang hendak dicoba oleh pelakon UMKM supaya sanggup terus bertahan serta jadi lebih responsive terhadap pergantian hawa bisnis.

\section{Metode Penelitian}

Memuat Penenlitian akan dilakukan terhadap usaha Jiwaku ricebowl yang bertempat di Jalan Taman Cempaka Bandung, dengan memakai metode kualitatif buat mendeskripsikan bagaimana kondisi usaha
Jiwaku ricebowl dalam suasana pandemi ini dengan pendekatan analisis SWOT. Bagi (Semiawan,2010) melaporkan tata cara riset kualitatif merupakan tipe tata cara riset yang sangat pas untuk menangkap anggaran manusia dengan kontak langsung serta fikiran terbuka dan melalui proses induktif serta interaksi simbolik manusia dapat memahami serta paham sesuatu. Karena sebagian besar usaha kecil dalam kondisi pandemi ini mengalami penurunan pendapatan.

Selain itu penulis akan melakukan wawancara dengan pemilik usaha untuk mendapatkan data primer dan mengumpulkan beberapa artikel yang terdapat kaitannya dengan penulisan, lalu mengambil kesimpulan dari beberapa artikel. Metode pengumpulan data yang diperlukan dalam riset ini merupakan observasi partisipasi dengan langkah eksporatif ialah melaksanakan salah satu metode pengumpulan data kualitatif yang di anjurkan buat memperoleh data-data deskriptif (Gunawan, 2017).

\section{Hasil dan Pembahasan}

Di tahun 2020, pertumbuhan penularan virus covid-19 lumayan signifikan sebab penyebarannya telah mendunia serta seluruh negeri merasakan dampaknya terutama di Indonesia (Yunus, 2020). menurut data resmi pemerintah 07 Mei 2020, permasalahan covid19 di Indonesia sudah terkonfirmasi adalah sebanyak 12.438 kasus (covid19.go.id). Bagi Febrantara (2020) serta OECD (2020), akibat pandemi Covid-19 pada UMKM bisa dilihat dari sisi penawaran serta sisi permintaan. Sedangkan sisi penawaran dengan terdapatnya pandemi Covid-19, beberapa UMKM hadapi kekurangan tenaga kerja. pelaku UMKM yang terdampak ketika di masa pandemi ini. Kesulitan atau masalah yang dialami oleh UMKM selama pandemi terdapat empat masalah (Sugiri D. , 2020) yaitu :

1. Terjadinya penurunan penjualan karena berkurangnya aktifitas masyarakat di luar sebagai pelaku 
FE Universitas Maritim Raja Ali Haji

konsumen.

2. Kesulitan dalam permodalan karena tingkat penjualanan yang menurun sehingga perputaran modal yang sulit

3. Pembatasan pergerakan penyaluran produk di wilayah tertentu menjadi hambatan pada distribusi produk.

4. Karena menggantungkan ketersediaan bahan baku dari sektor industry lain membuat UMKM kesulitan.

Dampak yang terjadi akibat pandemi ini sangat menghawatirkan karena berdasarkan survey yang dilakukan Katadata Insight Center (KIC) pada pelaku UMKM menunjukan bahwa hanya $5,9 \%$ UMKM yang sanggup memperoleh hasil positif di tengah pandemi ini. Pelaku usaha yang terdampak negative sebanyak $82,9 \%$ dan $63,9 \%$ dari mereka yang mengalami penurunan pendapatan sebanyak lebih dari $30 \%$.

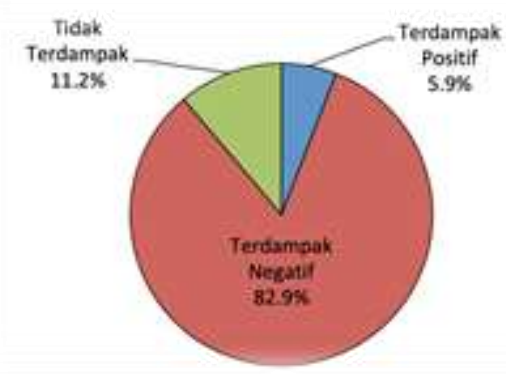

Gambar 1. Survei Katadata Insight Center 2020

Dari gambar diatas bisa disimpulkan bahwa banyaknya pelaku usaha yang terdampak negatif. Selain data diatas ada juga tabel yang diolah P2E LIPI :

Tabel 1. Jadwal Pelaksanaan Kegiatan

\begin{tabular}{|l|c|}
\hline $\begin{array}{l}\text { Dampak penurunan periwisata larhadap } \\
\text { UMKMI makanan dan minuman (mamin) } \\
\text { mikro }\end{array}$ & $27 \%$ \\
\hline Dampak usaha kecl makanan minuman & $1,77 \%$ \\
\hline Dampak usaha menengah & $0,07 \%$ \\
\hline
\end{tabular}

Maka dari itu pelaku UMKM harus menerapkan strategi terbaru yang lebih efektif untuk meningkatkan daya saing UMKM serta mempertahankan keberlangsungan UMKM. Terdapat sebagian perihal yang bisa dilakukan oleh UMKM contohnya:

\section{E-commerce}

Pada waktu pandemi covid-19, bagi Febrantara (2020) serta OECD (2020) , akibat virus Covid-19 terhadap UMKM bisa dilihat menurut sisi penawaran serta sisi permintaan. Dari sisi penawaran, terdapatnya pandemi Covid-19, banyak UMKM hadapi kekurangan tenaga kerja. Perihal itu terjalin sebab alibi melindungi kesehatan pekerja serta terdapatnya pemberlakuan pembatasan sosial (social distancing) disebabkan berujung pada keengganan warga buat bekerja sedangkan waktu dikala pandemi ini, sebaliknya pada sisi permintaan, permintaan barang serta jasa menurun dan berakibat pada UMKM tidak bisa berperan maksimal yang berujung pada minimnya likuiditas perusahaan.

Di Indonesia akibat pandemi Covid-19 pula dialami pada perekonomian zona UMKM sebab menurunnya perekonomian. Usaha Mikro Kecil serta Menengah (UMKM) adalah kelompok usaha orang skala kecil yang mempunyai bagian berarti dari roda perekonomian negeri. Berikut adalah klasifikasi UMKM :

1. Liverlhood Activities, merupakan Usaha Mikro Kecil dan Menengah (UMKM) yang merupakan usaha membuat peluang kerja untuk mencari nafkah, umumnya disebut sektor informal.

2. Micro Enterprise, ialah Usaha Mikro Kecil dan Menengah (UMKM) yang pelaku usahanya mempunyai keahlian pengrajin namun belum mempunyai watak kewirausahaan.

3. Small Dynamic Enterprise, ialah Usaha Mikro Kecil dan Menengah (UMKM) yang sanggup menerima pekerjaan subkontrak serta ekspor, mempunyai jiwa 
FE Universitas Maritim Raja Ali Haji

kewirausahaan

4. Fast Moving Enterprise, ialah Usaha Mikro Kecil dan Menengah (UMKM) yang akan melakukan perubahan menjadi usaha besar (UB) dan memiliki jiwa usaha yang baik (Resalawati, 2011).

Jika dilihat dari klasifikasi UMKM usaha Jiwaku ricebowl sudah termasuk Fast Moving Enterprise karena jiwaku ricebowl ini sudah bergabung dengan Contou coffee sehingga merupakan Usaha Mikro Kecil dan Menengah (UMKM) yang akan melakukan perubahan usaha menengah menjadi usaha besar (UB) dan memiliki jiwa usaha yang baik. E-commerce juga sangat membantu konsumen merasa lebih luas dan tak terbatas untuk memilih apa yang mereka butuhkan, selain menjadi keuntungan bagi konsumen pelaku usaha juga tidak perlu mencetak katalog karena konsumen bisa langsung melihat seperti promosi dan lainnya via $e$ commerce. Dalam usaha Jiwaku Ricebowl ,mereka sudah menerapkan cara ini semenjak awal PSBB dengan menerapkan sistem preorder melalui akun instagram Jiwaku. Semenjak dilakukannya sistem pre-order, menurut owner atau pemilik dari Jiwaku ini omset atau pemasukannya meningkat :

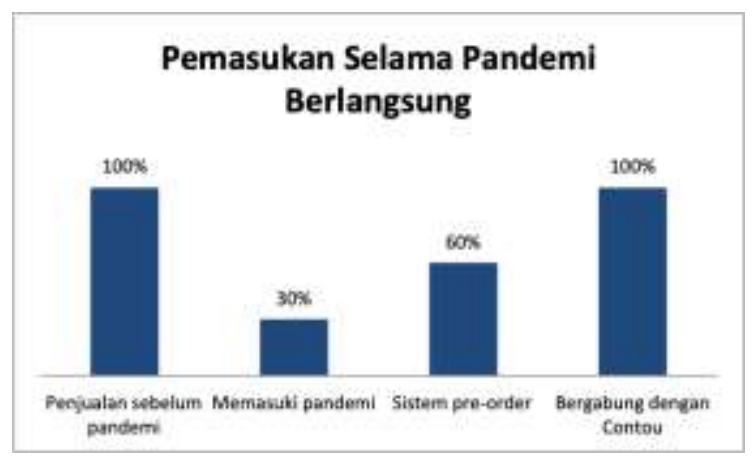

Gambar 1. Survei Katadata Insight Center 2020

Dari gambar tersebut pada tanggal 10 Maret 2020 virus corona mulai memasuki negara Indonesia dan diberlakukan Pembatasan Sosial Berskala Besar (PSBB). Setelah di berlakukannya PSBB pendapatan dari Jiwaku ini menurun $70 \%$ dari biasanya dan mengalami penutupan sementara selama
2 minggu karena arahan dari pemerintah dikarenakan kota Bandung banyak yang terpapar virus, setelah libur 2 minggu jiwaku ini mulai membuka usahanya lagi tetapi diberlakukan pre-order dirumah pemilik dengan sistem take away.

Dengan diadakannya sistem pre-order pendapatan naik hingga $30 \%$ dari sebelumnya, memasuki bulan puasa jiwaku ricebowl bergabung dengan Contou coffee jalan taman cempaka sehingga pendapatannya naik lagi sebesar $40 \%$ sehingga jiwaku ini memiliki 2 tempat yaitu di Taman Cibeunying dan Contou coffee. Namun dikarenakan lokasi di Taman Cibeunying kurang kondusif sehinggal owner dari jiwaku ini akan menfokuskan kepada cabang yang ada di Contou.

\section{Analisis SWOT}

Peneliti melakukan penelitian kualitatif dalam bidang analisis SWOT untuk merumuskan strategi pemasaran mana yang dapat diterapkan pada UMKM Jiwaku Ricebowl dengan pengambilan data melalui triangulasi data yaitu dengan cara wawancara, pengamatan atau observasi, dan dilakukan pula kajian data atau dokumen guna memperkuat data yang dibutuhkan oleh peneliti.

Analisis SWOT dilakukan agar penulis bisa mengetahui keadaan yang terjadi pada usaha jiwaku ricebowl ini.

1) Strengths (kekuatan), kekuatan dari jiwaku ini sudah mempunyai kostumer loyal dan rasa dari setiap ricebowl yang ada di pasaran pasti berbeda.

2) Weaknesses (kelemahan), kelemahan dari usaha ini adalah kurangnya konsep dari marketing itu sendiri dan dalam media social yang mereka punya.

3) Opportunities (peluang), peluang jiwaku ricebowl ini tetap menjadi pilihan makanan utama di Contou coffee sehingga otomatis apabila mampir ke Contou coffee dan ingin memesan makanan diarahkan kepada jiwaku ricebowl ini.

4) Threats (ancaman), ancaman Jiwaku ini lumayan banyak disebabkan pada tahun 2021 semakin banyak pesain karna usaha ricebowl saat ini sedang naik 
daun.

Riset ini dilakukan buat mengenali apa yang dicoba pelakon UMKM agar bisa mempertahankan bisnis mereka di masa Pandemi covid-19 ini. Riset ini bertujuan buat mendeskripsikan serta menjabarkan strategi apa yang hendak dicoba oleh pelakon UMKM supaya sanggup terus bertahan serta jadi lebih responsive terhadap pergantian hawa bisnis.

\section{Kesimpulan}

Hasil dari pembahasan bisa berdampak besar bagi sektor di seluruh dunia termasuk Indonesia seperti sektor ekonomi, kesehatan, politik dan juga pendidikan. Dalam penelitian ini kami membahas tentang salah satu UMKM yang mana UMKM sangat terasa dampak dari covid-19 ini, di Bandung yaitu Jiwaku. Seperti yang terjadi pada usaha Jiwaku ini pendapatan dari usaha mereka turun sebesar $70 \%$.

\section{Saran}

Sebaiknya Jiwaku ini lebih mematangkan konsep dari marketing itu sendiri kalau dilihat dari kelemahan SWOT dikarenakan masih banyak orang yang belum mengenal rasa dan makanan dari Jiwaku ini, dengan memperluasnya ide marketing atau strategi marketing itu sendiri merupakan sebuah peluang besar untuk Jiwaku ini lebih dikenal beberapa masyarakat.

Apabila dilihat dari ancaman banyaknya pesaing dari penjual lainnya yang sudah banyak membuat ricebowl ini. Dengan itu Jiwaku bisa berinovasi atau membuat menu ciri khas yang berbeda dari penjual lainnya agar mengurangi ancaman untuk usaha Jiwaku tersebut.

\section{Daftar Pustaka}

Aisyah, Siti.(2020). Dampak Pandemi Covid19 Bagi UMKM Serta Strategi Emarketing UMKM di Indonesia

\section{Alfin, A.(2019). Analisis Strategi UMKM dalam menghadapi krisis di era pandemi covid-19 . Jurnal Inovasi Penelitian 1(8).}

Amri, A.(2019). Dampak Covid-19 Terhadap
UMKM di Indonesia. Jurnal Brand, Volume 2 No 1, Juni 2020.

Febrantara, D. (2020). Bagaimana

Penanganan UKM di Berbagai Negara

Saat Ada Pandemi Covid-19? DDTC

Fiscal Research. Retrieved from

https://drive.google.com/drive/folders/ $1 \mathrm{MY} 31 \mathrm{IOC} 3 \mathrm{gWq}-$

EgzNkuJzqJnB9PV6qA2D

Gunawan, I. (2017). Metode Penelitian Kualitatif. In Bumi Aksara (5 ${ }^{\text {th }}$ ed.).

Hardilawati, W. L.(2019). The Role of Innovation and E-Commerce in Small Business.373,83-87.

Husodo dkk. (2020) Analisis Dampak Covid-

19 Terhadap Pendapatan UMKM

(Usaha Kecil Menengah) Desa Blado, Kabupaten Batang.

Irene, Saleh, R. R., Foresto, B., Djuanda, R. E., Prayogo, A., Arianti, A., et al. (2020, Maret 18). Pesan Para Dokter terkait Covid-19. Dipetik April 18, 2020, dari YouTube alobatnic: https://youtu.be/F1IiXodT3MQ

Kotler, Philip dan Amstrong, G. (2012). Principles of Marketing (15th ed.). Pearson Education Limited.

Nur Rohim Yunus, Annissa Rezki. (2020). Kebijakan Pemberlakuan Lockdown Sebagai Antisipasi Penyebaran Corona Virus Covid-19. Jurnal Sosial \& Budaya Syar-i. Vol. 7, pp.227-238.

OECD. (2020). SME Policy Responses: Tackling Coronavirus (Covid-19) Contributing to A Global Effort. Retrieved from https://oecd.dambroadcast.com/pm $7379119 \quad 119680-$ di6h3qgi4x.pdf

Prabowo, W. A. 2018. Pengaruh Digital Marketing terhadap Organizational Performance dengan Intellectual Capital dan Perceived Quality sebagai Variabel Intervening pada Industri Hotel Bintang Tiga di Jawa Timur. Jurnal Manajemen Pemasaran. Vol 12 (2). 101-112 pp. https://doi.org/10.9744/pemasaran.12.2 $.101-112$ 
FE Universitas Maritim Raja Ali Haji

Semiawan, C.R. (2010). Metode Penelitian

Kualitatif: Jenis, Karakteristik dan

Keunggulan (Arita L (ed)). Grasindo

Setyorini, D., Nurhayati, E., \& Rosmita. (2019). Pengaruh Transaksi Online ( $e$ Commerce) Terhadap Peningkatan Laba UMKM (Studi Kasus UMKM Pengolahan Besi Ciampea Bogor Jawa Barat). Jurnal Mitra Manajemen (JMM Online), 3(5), 501-509.

Sugiri, D. (2020). Menyelamatkan Usaha Mikro Kecil dan Menengah dari Dampak Pandemi Covid-19. Fokus Bisnis: Media Pengkajian Manajemen dan Akuntansi, 4.

Suryani, Evi (2021). Analisis Dampak Covid19 Terhadap UMKM (Studi Kasus : Home Industri Klepon di Kota Baru Driyorejo).

Wan, Laura Hardilawati (2020). Strategi Bertahan UMKM di Tengah Pandemi Covid-19, Jurnal Akuntansi \& Ekonomika, Vol. 10 No. 1, Juni 2 